JINOTEP Vol 6 (2) (2020): 103-110

DOI: $10.17977 /$ um031v6i22020p103

JINOTEP (Jurnal Inovasi Teknologi Pembelajaran)

Kajian dan Riset Dalam Teknologi Pembelajaran

http://journal2.um.ac.id/index.php/jinotep/index

\title{
PENGEMBANGAN MULTIMEDIA MOBILE LEARNING BERBASIS SMARTPHONE ANDROID MATERI HURUF MADURA UNTUK SD NEGERI 1 PERANTE KABUPATEN SITUBONDO
}

\author{
Bayu Nurhidayat, Agus Wedi, Henry Praherdhiono \\ Jurusan Teknologi Pendidikan, Fakultas Ilmu Pendidikan, Universitas Negeri Malang \\ Jalan Semarang 5 Malang 65145
}

\section{Article History}

Received:24-05- 2019

Accepted: 26-06-2019

Published: 30-04-2020

\section{Keywords}

Pengembangan, Multimedia Mobile Learning, Bahasa Madura

\begin{abstract}
Abstrak
Tujuan Pengembangan ini adalah menghasilkan produk aplikasi mobile learning pembelajaran berbasis smartphone android yang digunakan pada pelajaran Bahasa Madura tentang materi huruf Madura. Penelitian ini berfokus menghasilkan multimedia pemebalajaran mobile learning untuk meningkatkan pemahaman materi Bahasa Madura. Prosedur pengembangan multimedia pembelajaran mobile learning menggunakan model Lee, W.W., \& Owens, D.L. (2004) Hasil yang diperoleh dari validasi ahli media keseluruhannya yaitu sebesar $79.16 \%$ berdasarkan kriteria media termasuk valid dan layak digunakan dalam pembelajaran. Hasil validasi ahli materi diperoleh hasil keseluruhan sebesar 89,5.7\% berdasarkan kriteria media termasuk valid dan layak digunakan dalam pembelajaran.Hasil uji coba pada siswa diperoleh hasil keseluruhan $97 \%$ yang berdasarkan kriteria media termasuk valid dan layak digunakan dalam pembelajaran. Hasil pre-test dan post-test siswa terdapat peningkatan nilai sebesar $100 \%$ yang berdasarkan kriteria termasuk dalam kriteria yang ekertif saat digunakan dalam pembelajaran.
\end{abstract}

\begin{abstract}
The purpose of this development is to produce a mobile smartphone-based learning application product that is used in Madura Language lessons about Madura letter material. This study focuses on producing multimedia learning for mobile learning to improve understanding of Madurese language material. The procedure for developing multimedia learning for mobile learning uses the models of Lee, W.W., \& Owens, D.L. (2004) The results obtained from the overall media expert validation were $79.16 \%$ based on media criteria including valid and appropriate to be used in learning. The results of the material expert validation obtained overall results of $89.5 .7 \%$ based on media criteria including valid and feasible to be used in learning. The results of trials on students obtained 97\% overall results based on media criteria including valid and appropriate to be used in learning. The results of the pre-test and post-test students have an increase in the value of $100 \%$ based on the criteria included in the criteria that are accurate when used in learning.
\end{abstract}

Corresponding author:

2020 Universitas Negeri Malang p-ISSN 2406-8780 e-ISSN 2654-7953 
104 JINOTEP (Jurnal Inovasi dan Teknologi Pembelajaran) Kajian dan Riset dalam Teknologi Pembelajaran Vol.6, No.2, April 2020, Hal. 103-110

\section{PENDAHULUAN}

Media Pembelajaran merupakan salah satu komponen lingkungan belajar memberikan sumbangan terhadap kemampuan pengguna dalam mengakses material pembelajaran secara demokratis (Praherdhiono,2016). Media pembelajaran diperlukan dalam setiap pembelajaran termasuk dalam Pendidikan sekolah dasar. Lingkungan belajar dalam Pendidikan formal akan memberikan kenyamanan dalam belajar dan pembelajaran (Praherdhiono, 2014).

Pendidikan sekolah dasar meupakan sebuah tahapan paling dasar dalam Pendidikan formal yang mempunyai peranan besar bagi keberlangsungan proses penidikan selanjutnya. Tujuan Pendidikan sekolah dasar adalah meletakkan dasar kecerdasan, pegetahuan, kepribadian,ahlak mulia,serta keterampilan buat hayati berdikari serta mengikuti Pendidikan lebih lanjut. Sekolah Dasar memerlukan lingkungan belajar yang mampu mengelola media pembelajaran. Sekolah Dasar merupakan jenjang Pendidikan dasar yang diselenggarakan satuan Pendidikan formal di Indonesia (Passe, 1999).

Mobile learning adalah persimpangan Mobile Computing dan E-Learning yang menyediakan sumber daya yang dapat diakses dari mana saja, kemampuan sistem pencarian yang kuat, interaksi yang kaya, dukungan penuh untuk pembelajaran yang efektif dan penilaian berdasarkan kinerja. E-learning memiliki karakteristik independen terhadap tempat dan waktu (A.N.A Thohari,2013). Mobile Learning berhubungan dengan mobilitas belajar, dalam arti pelajar semestinya mampu terlibat dalam kegiatan Pendidikan tanpa harus melakukan di sebuah lokasi fisik tertentu. (Panji Wisnu Wirawan,2011:22-23)

Memahami merupakan tujuan pembelajaran ranah kognitif setelah mengingat, taksonomi bloom revisi Anderson dalam (Gunawan dan Palupi, 2016). Terdapat enam tingkatan dalam taksonomi Bloom, yaitu: (C1) mengingat, (C2) memahami, (C3) menerapkan, (C4) menganalisis, (C5) mengevaluasi dan (C6) mencipta. Kemampuan memahami merupakan kamampuan dasar yang penting dikuasai siswa untuk mencapai hasil belajar. Siswa tidak hanya mengingat tetapi juga memahami, oleh sabab itu pemahaman materi perlu dikuasai sejak Sekolah Dasar. Anak Sekolah Dasar berada pada periode perkembangan kognitif tahap operasional konkret (Ibda, 2015). Anak masih belajar dengan menggunakan objek konkret untuk mengembangkan intelektualnya. Mereka mulai sudah dapat memahami tentang menulis, berhitung dan berkorespondensi (mengubungkan antara bentuk dan isi) serta sudah mulai belajar berpikir secara abstrak namun masih sederhana (Desstya, 2014).

Bahasa Madura (Bhâsa Mâdhurâ) adalah bahasa yang digunakan Suku Madura. Bahasa Madura mempunyai penutur kurang lebih 14 juta orang dan terpusat di Pulau Madura, Ujung Timur Pulau Jawa atau di kawasan yang disebut kawasan Tapal Kuda terbentang dari Pasuruan, Surabaya, Malang, sampai Banyuwangi, Kepulauan Masalembo, hingga Pulau Kalimantan.

Bahasa Madura merupakan anak cabang dari bahasa Austronesia ranting MelayuPolinesia, sehingga mempunyai kesamaan dengan bahasa-bahasa daerah lainnya di Indonesia. Bahasa Madura banyak terpengaruh oleh bahasa Jawa (terutama Jawa Suroboyoan), Melayu, Arab, Tionghoa, dan beberapa bahasa lainnya. Pengaruh bahasa Jawa sangat terasa dalam bentuk unggah-ungguh (tingkatan) bahasa sebagai akibat pendudukan kerajaan Mataram Islam atas Pulau Madura. Sebagian besar kata-kata dalam bahasa Madura berakar dari bahasa Melayu, bahkan ada beberapa kata yang mirip dengan yang ada pada dengan bahasa Minangkabau, tetapi sudah tentu dengan lafal yang berbeda. Minangkabau mengucapkan "a" sebagai "o" pada posisi akhir, sedangkan pada bahasa Madura, diucapkan "ə" ("e" pepet) atau "a". bahasa Madura adalah bahasa daerah yang di samping sebagai bahasa 
nasional juga berfungsi untuk dipakai sebagai bahasa perhubungan intradaerah oleh penduduk Pulau Madura dan pulau-pulau sekitarnya ( Effendy,2019)

Penelitian ini bertujuan untuk: (1) menghasilkan produk Adaptive Mobile Learning yang layak menurut ahli materi, ahli media dan pengguna, (2) mengetahui kebermanfaatan produk melalui ketuntasan hasil belajar peserta didik, dan kemampuan program untuk mendukung blended learning. (Surahman, E., \& Surjono, H. D. 2017).

Berdasarkan observasi di SDN 1 Perante Situbondo, menemukan beberapa hambatan dalam kegiatan belajar di kelas pada materi Bahasa Madura kelas V. Dari hasil wawancara guru mata pelajaran metode ceramah masih dilakukan sehingga siswa merasa bosan dikelas. Penjelasan materi oleh guru dari buku guru yang disediakan oleh sekolah kurang menarik serta siswa membutuhkan media yang fleksibel dan mudah digunakan dimana saja. Ketika proses pembelajaran juga tidak terjadi timbal balik ketika guru bertanya karena kurang antusiasnya siswa dalam proses pembelajaran.

Pada pembelajaran Bahasa Madura kelas $\mathrm{V}$ yang membahasa materi tentang penulisan huruf adura juga pengenalan budaya madura. Buku yang dijadikan bahan ajar hanya memberikan sedikit materi, sehingga berdampak pada kurangnya pemahaman siswa. Dari hambatan hasil observasi, penelitian ini mengembangkan media multimedia mobile learning berbasis smartphone android di mana siswa juga guru rata rata sudah menggunakan smartphone berbasis android.

Berdasarkan uraian diatas, maka tujuan penelitian ini adalah menghasilkan produk aplikasi mobile learning pembelajaran berbasis smartphone android yang digunakan pada pelajaran Bahasa madura tentang materi huruf madura siswa SDN 1 Perante Kecamatan Asembagus Kabupaten Situbondo.yang valid dan efektif digunakan dalam proses pembelajaran.

\section{METODE}

Model Penelitian ini tegolong penelitian dan pengembagan (Research and Development). Menurut Sugiyono (2013) "Metode Penelitian dan Pengembangan adalah metode penelitian yang digunakan untu menghasilkan produk tertentu, dan menguji keefektifan produk tersebut". Model pengembangan yang digunakan adalah model William W, Lee dan Dianda L. Owens (2004) dengan tahapan, diantaranya analisis (analysis), desain (design), pengembangan (development), implementasi (implementation), dan evaluasi (evaluation).

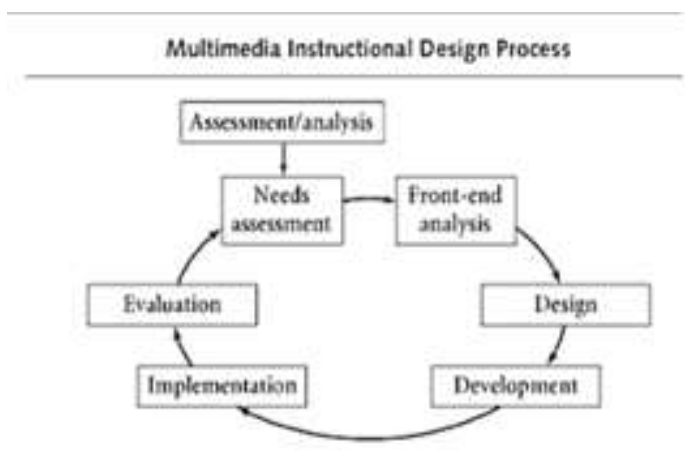

Gambar 1. Prosedur Pengembangan Model William W. Lee dan Diana L. Owens (2004)

\section{Analisis}

Tahap pertama adalah analisis. Kegiatan anlaisis meliputi analisis kerja, analisis kebutuhan dan analisis awal dan akhir (Lee \& Owens, 2004).

Analisis kebutuhan

Hasil obeservasi yang sudah dilakukan diperoleh hasil guru menggunakan metode ceramah dengan modul, sedangkan dalam modul belum ada Teknik cara menulis dan melafalkan huruf madura

Analisis Awal dan akhir

Front-end Analysis merupakan tahap menganalisis data dan informasi yang sudah di kumpulkan untuk menentukan data dan informasi yang akan digunakan dari keseluruhan data yang telah di peroleh. Dalam penelitian ini tahap Front-end analysis ada beberapa kegiatan, antara lain : 
106 JINOTEP (Jurnal Inovasi dan Teknologi Pembelajaran) Kajian dan Riset dalam Teknologi Pembelajaran Vol.6, No.2, April 2020, Hal. 103-110

1). Analisis Siswa

Berdasarkan data dari analisis siswa yang diperoleh, pemahaman materi menjadi masalah utama perlu adanya media yang membuat pembelajaran menjadi menyenagkan dan membuat siswa lebih senang dalam proses pembelajaran. Media tersebut diwujudakan dalam media mobile learning berbasis smartphone android. Media mobile learing dipilih karena mayoritas anak jaman sekrang mempunyai android yang bisa dimanfaatkan untuk proses pembelajaran dan sangat mudah dalam pengoprasiannya.

\section{2). Analisis Teknologi}

Untuk analisis teknologi sendiri guru dan siswa di SDN 1 Perante Situbondo rata rata sudah memiliki smartphone berbasis android. Untuk proses penyebaran yaitu dengan bentuk aplikasi yang telah di burning kedalam CD juga bisa menggunakan flasdisk.

\section{3). Analisis Situasi}

Dalam anaisis situasi ini tidak ditemukan kendala dalam lingkungan belajar di SDN 1 Perante Situbondo, lingkungan di sana sudah cukup baik sehingga mendukung kegiatan belajar.

\section{4). Analisis Tugas}

Dengan aplikasi ini siswa diharapkan mampu menulis aksara madura dengan baik, siswa ajuga diharapkan mampu mengucapkan kalimat Bahasa madura dengan lancer dan benar sesuai aturan di Bahasa madura.

\section{5). Analisis Kejadian Penting}

Untuk analisis kejadian penting animasi Teknik menulis huruf madura menjelaskan bagaimana cara penulisan huruf madura yang benar dan audio berisi bagaimana bunyi pelafalan di setiap huruf madura

\section{6). Analisis Masalah}

Dari identifikasi masalah yang diperoleh pada saat observasi. Pengembang memperoleh hasil bahwa SDN 1 Perante
Situbondo dalam pengembangan aplikasi tidak ditemukan kendala karena sarana dan prasarana sangat memadai. Namun penyampaian materi harus didampingi oleh guru supaya tetap terkontrol.

7). Analisis Tujuan

Analisis Tujuan dalam pengembangan ini adalah untuk mengetahui valid tidaknya aplikasi android ini dikemabnagkan di SDN 1 Perante Situbondo, selain itu siswa diharapkan mampu menguasai materi menulis dan melafalkan huruf madura dengan baik dan benar.

\section{8). Analisis Media}

Produk aplikasi android ini memiliki beberapa elemen seperti teks,gambar,audio,dan animasi. Elemen teks digunakan dalam penyampaian materi teks tercantum pada judul menu, petunjuk, materi, gambar yang dimasukan merupakan gambar yang memvisualisasikan huruf madura. Audio yang dimasukan sebagai contoh pelafalan huruf madura. Sedangkan animasi sebagai alat untuk memudahkan bagaimana cara menulis huruf hiragam.

\section{9). Analisis Data}

Analisis data Dilakukan untuk mengidentifikasi, menentukan isi materi yang akan ditampilkan dalam media. Dalam Produk aplikasi android ini berpacu pada pada Buku Mata Pelajaran Bahasa Madura SDN 1 Perante Situbondo.

\section{0). Analisis Biaya}

Pada tahap analisis biaya ini mencakup kegiatan penentuanbiaya, penggunaan biaya dan mencatat hasil akhir biaya. Banyaknya biaya yang diperlukan dalam pembuatan media dijelaskan secara rinci. Dalam Penelitian dan pengembangan ini biaya dapat diminamalisir dengan menggunakan sarana dan prasarana yang ada di sekolah, sehingga hanya cukup menyediakan produk aplikasi android saja. 


\section{Desain}

Dalam tahap desain terdapat tahap perencanaan dari produk/media yang akan di kembangkan menurut Lee dan Owens (2004) terdapat beberapa kegiatan yang perlu dilakukan dalam tahap desain ini, antara lain jadwal kegiatan (Schedule), tim proyek (Project Team). Spesifikasi media (media specification). Struktur konten (Lesson Structure). Kontrol Konfigurasi (Configuration Conrol).

Materi yang akan di sajikan dalam media aplikasi yaitu tentang Mata Pelajaran Bahasa madura dengan materi huruf madura serta tambahan sedikit tentang budaya suku madura untuk kelas 5 Sekolah Dasar. Selanjutnya kegiatan perancangan produk meliputi pembuatan storyboard, Jadwal kegiatan, merekam dubbing, dan struktur konten .

\section{Pengembangan dan Pelaksanaan}

Tahap pengembangan dan pelaksanaan merupakan kegiatan produksi media aplikasi berbasis smartphone android dari storyboard yang telah dirancang sebelumnya. Software yang akan digunakan. Dalam produksi media media pembelajaran materi huruf madura ini menggunakan adobe animated $\mathrm{CC}$ sebagai software utama untuk membuat produk mulai dari animasi hingga tampilan aplikasi, dan adobe illustrator CS6 digunakan untuk mendesign gambar yang akan di masukkan dalam aplikasi juga adobe audition CS6 sebagi software untuk mengedit suara atau dubbing, dari beberapa elemen tersebut akan digabungkan untuk menjadi kesatuan dalam aplikasi hingga selesai dan sampai pada tahap pengecekan akhir.

Tahap selanjutnya uji validaitas untuk mengetahui kevalidan media video pembelajaran. Validasi media dilakukan oleh ahli media dan ahli materi Ahli media yang dipilih adalah dosen Jurusan Teknologi Pendidikan dengan pendidikan akhir S2 dan memiliki keahlian tentang multimedia mobile learning. Ahli materi adalah guru pengajar yang memiliki pengalaman mengajar Bahasa Madura di SDN 1 Perante dengan pendidikan akhir minimal S1.

Tahap Mengimplementasikan produk atau pelakasanaan yang sudah di review oleh pengembang,ahli media dan ahli materi akan di uji cobakan pada siswa yang mengikuti mata pelajaran Bahasa madura untuk Kelas V di SDN 1 Perante Situbondo sebanyak 17 siswa.

Pendapat Arsyad (2002) mengenai manfaat pembelajaran menggunakan media akan membantu proses pembelajaran. Penyampaian pesan dan isi materi dapat diterima dengan baik oleh siswa.

\section{Evaluasi}

Dalam Tahap evaluasi, beberapa langkah yang harus dilakukan antara lain menentukan tujuan evaluasi untk mengukur kevalidan dari suatu prosuk yang dihasilkan yang sebelumnya akan di ujicobakan kepada ahli media, ahli materi, dan siswa mata pelajaran Bahasa madura. Menyusun dan merencanakan strategi evaluasi untuk pemberian angket kepada ahli media, ahli materi sebelum di uji cobakan terhadap siswa. Mengukur validitas yaitu untuk mengukur tampilan produk apakah cocok untk digunakan sebagai media pembelajaram. Pengembangan instrument dan mengumpulkan analaisis data yang terdiri dari 1 ahli media, 1 ahli materi, dan 17 siswa mata pelajaran Bahasa madura. Instrumen pengumpulan data adalah alat bantu, merupakan sarana yang dapat diwujudkan dalam benda, misalnya angket (questionnaire), daftar periksa (checklist) atau pedoman wawancara, lembar observasi dan lain sebagainya (Arikunto,2000).

\section{HASIL BELAJAR}

Pada tahap ini akan diuraikan data hasil uji coba dan Analisa data yang diperoleh dari ahli media, ahli materi dan responden. Data uji coba ahli media diperoleh dari satu orang ahli media pembelajaran, yaitu dosen jurusan Teknologi Pendidikan Universitas Negeri Malang. Data Uji coba ahli materi diproleh dari satu orang ahli materi guru Bahasa madura di 
108 JINOTEP (Jurnal Inovasi dan Teknologi Pembelajaran) Kajian dan Riset dalam Teknologi Pembelajaran Vol.6, No.2, April 2020, Hal. 103-110

SDN 1 Perante Situbondo. Responden siswa sebanyak 17 siswa.

Analisis data dari ahli media yaitu memperoleh hasil 79,16\%. Berdasarkan kriteria yang ditetapkan dapat dujelaskan bahwa pengembangan multimedia mobile learning materi huruf madura untuk kelas V Sekolah Dasar termasuk dalam kriteria valid dan layak untuk dimanfaatkan dalam pembelajaran.

Analisis data dari ahli materi yaitu memperoleh hasil 89,5\%. Berdasarkan kriteria yang ditetapkan dapat dujelaskan bahwa pengembangan multimedia mobile learning materi huruf madura untuk kelas V Sekolah Dasar termasuk dalam kriteria valid dan layak untuk dimanfaatkan dalam pembelajaran.

Analisis data audiens/siswa dalam uji coba lapangan diperoleh hasil $\mathbf{9 7 \%}$. Berdasarkan kriteria yang telah ditetapkan dapat dijelaskan bahwa bahwa pengembangan multimedia mobile learning materi huruf madura untuk kelas V Sekolah Dasar termasuk dalam kriteria valid dan layak untuk dimanfaatkan dalam pembelajaran.

\section{Diagram Hasil Analisis}

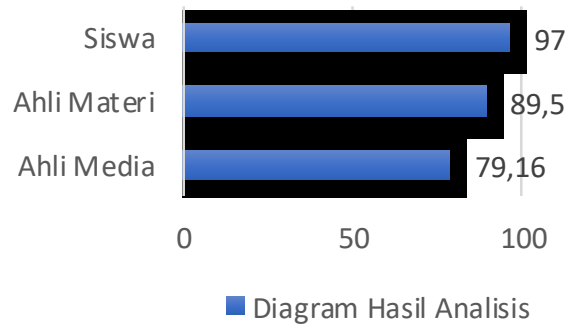

Gambar 2. Hasil Analisis Data

Setelah dilakukan uji coba Hasil pre-test dan post-test yang telah dilakukan oleh siswa terdapat peningkatan sebesar $100 \%$. Berdasarkan kriteria dapat disumpulkan media aplikasi berbasis smartphone android termasuk dalam kriteria efektif dapat meningkatkan pemahaman siswa terhadap materi Bahasa madura dalam proses pembelajaran.

\section{PEMBAHASAN}

Kemampuan menulis awal ketentuan utama bagi anak-anak untuk dapat memahami mata pelajaran yang diberikan di sekolah. Salah satu alternatif untuk membantu meningkatkan minat dan kemampuan anak dalam belajar membaca dan menulis adalah menggunakan media pembelajaran dalam bentuk perangkat lunak.

Android adalah alternatif perangkat lunak yang dipilih, dengan alasan android cenderung digunakan pada perangkat seluler seperti Smartphone dan tablet PC ( Hendrawan, 2012 ).

Ada beberapa alasan perangkat seperti smartphone dipilih sebagai perangkat untuk mengoperasikan media pembelajaran, antara lain : 1) penetrasi perangkat sangat cepat, 2) Jumlah perangkat smartphone lebih banyak dibandingkan komputer, 3) Lebih dioperasikan dari pada komputer. (Darmawan,2013:15).

Mobile learning merupakan salah satu tren dalam bidang teknologi pendidikan dewasa kini diharapkan mampu memfasilitasi kebutuhan belajar semua kalangan. Di samping itu mobile learning dapat menjadi solusi permasalahan pemerataan dan keterbatasan akses pendidikan. (Surahman, E. 2019)

Meultimedia pembelajaran mobile learning dengan materi huruf madura yang dikembangkan antara lain memuat teks, gambar, video, audio, dan animasi.

Media pembelajaran materi huruf madura yang dikembangkan ini memperoleh hasil validasi dari ahli media sebesar $79,16 \%$, ahli materi sebesar $89,5 \%$ dan uji coba audiens sebesar $100 \%$ diperoleha dari hasil validasi tersebut media pembelajaran materi huruf madura valid dan layak digunakan dalam proses pembelajaran siswa Sekolah Dasar.

Hasil Uji coba pre-test dan post-test mata pelajaran Bahasa madura dair 17 siswa mengalami peningkatan nilai hingga $100 \%$. Dari hasil tersebut dapat disimpulkan bahwa 
siswa mengalami peningkatan pemahaman siswa pada proses belajar.

Revisi produk merupakan hasil kesimpulan dari hasil analisa data ahli media, ahli materi, dan ujicoba audiens mengenai permainan elektronik yang divalidasikan agar produk tersebut sempurna dan lebih efektif untuk kegiatan pembelajaran. Revisi produk tersebut meliputi:

\section{1). Tanggapan Ahli Media}

Ahli Media memberi tanggapan dimana font dalam aplikasi di perbesar dan menggunakan font yang jelas, serta pada aplikasi bagian materi supaya di tambah contoh dalam bentuk animasi dan ditambah narasi.

\section{2). Tanggapan Ahli Materi}

Berdasarkan tanggapan oleh ahli materi dimana aplikasi tersebut penyampaian materi terlalu cepat dan berharap bisa mengembangkan aplikasi dengan materi yang lebih lengkap dengan versi yang lebih detail.

\section{3). Tanggapan Siswa}

Tanggapan dari siswa sendiri yaitu berpendapat bahwa backsound supaya diganti yang lebih nyaman untuk di dengarkan, selebihnya siswa merasa sangat senang menggunakan aplikasi berbasis smartphone tersebut sehingga dapat membuat siswa lebih aktif dan giat dalam proses pembelajaran.

\section{SIMPULAN}

Multimedia Mobile Learning berbasis Smartphone Android mata pelajaran Bahasa madura materi huruf madura di Sekolah Dasar kelas V memiliki kedudukan sebagai suplemen (tambahan) dalam proses pembelajaran, yang bisa digunakan di dalam maupun di luar sekolah yang mampu meningkatkan pemahaman tentang pelejaran Bahasa madura dan membuat siswa tidak jenuh dengan pelajaran yang selalu menggunakan modul.Aplikasi ini juga menghasilkan produk berupa aplikasi dalam bentuk apk yang di kemas dalam bentuk CD (Compact Disk), dengan itu aplikasi ini bisa dengan gampang di sebarkan dari 1 siswa ke siswa lainnya.

berdasarkan tujuan penelitian pengembangan, pembelajaran multimedia mobile learning memenuhi kriteria valid. Artinya pembelajaran mobile learning yang dikembangkan layak dan efektif mampu meningkatkan pemahanan siswa dan dapat membuat siswa lebih aktif lagi. Aplikasi tersebut juga dapat digunakan dalam proses pembelajaran di dalam maupun dilar kelas.

\section{DAFTAR RUJUKAN}

Arikunto. S, 2000. Manajemen Penelitian. Jakarta: PT. Rineka Cipta

Arsyad, A., 2002. Media pembelajaran, edisi 1. Jkt. PT Raja Graf. Persada 36.

Darmawan. 2013. Metode Penelitian Kuantitatif. Bandung: Remaja Rosdakarya.

Desstya, A. 2014. kedudukan dan aplikasi pendidikan sains di Sekolah Dasar. Profesi Pendidikan Dasar, 2(1), 193-200.

Effendy, M. H. (2019). Peningkatan Kemampuan Berbahasa Madura Yang Baik Dan Benar Pada Masyarakat Dusun Banlanjang Tlonto Raja Kecamatan Pasean di Masjid Al Muttaqin. PERDIKAN (Journal of Community Engagement), 1(1).

Gunawan, I., \& Palupi, A. R. (2016). Taksonomi Bloom-revisi ranah kognitif: kerangka landasan untuk pembelajaran, pengajaran, dan penilaian. Premiere educandum: jurnal pendidikan dasar dan pembelajaran, 2(02).

Hendrawan, D. S. (2013). Aplikasi belajar menulis untuk anak pra sekolah berbasis android.

Ibda, F. (2015). Perkembangan kognitif: teori jean piaget. Intelektualita, 3(1)

Lee.W.W. \& Owen. D. L. 2004. Multimedia based instructional design, second edition.

Passe, J., (1999). Elementary school curriculum. McGraw-Hill College.

Praherdhiono, H. (2014). Convenience of Learning Environment for Student Special Education With Cyberwellness Concept. Proceeding International postdraduate University Kebangsaan Malaysia. SEAMOSEN.

Praherdhiono, H. (2016). Standar Program Pengukuran Kenyamanan Lingkungan Belajar Berbasis Ergonomi. Disertasi Dan Tesis Program Pascasarjana UM. 
110 JINOTEP (Jurnal Inovasi dan Teknologi Pembelajaran) Kajian dan Riset dalam Teknologi Pembelajaran Vol.6, No.2, April 2020, Hal. 103-110

Sugiyono,2013. Metodologi Penelitian Kuantitatif,kualitatif dan R\&D. (Bandung: ALFABETA)

Surahman, E., \& Surjono, H. D. (2017). Pengembangan adaptive mobile learning pada mata pelajaran biologi SMA sebagai upaya mendukung proses blended learning. Jurnal Inovasi Teknologi Pendidikan, 4(1), 26-37.

Surahman, E., \& Alfindasari, D. (2017, September) Developing Adaptive Mobile Learning with the Principle of Coherence Mayer on Biology Subjects of High School to Support the Open and Distance Education. In 3rd International Conference on Education and Training (ICET 2017). Atlantis Press.
Surahman, E. (2019). Integrated Mobile Learning System (Imoles) Sebagai Upaya Mewujudkan Masyarakat Pebelajar Unggul Era Digital. JINOTEP (Jurnal Inovasi Dan Teknologi Pembelajaran) Kajian Dan Riset Dalam Teknologi Pembelajaran, 5(2), 50-56.

Thohari, A. N. A., Satoto, K. I., \& Martono, K. T. (2013). Pembuatan Aplikasi Mobile Learning sebagai Sarana Pembelajaran di Lingkungan Universitas Diponegoro. Jurnal Teknologi dan Sistem Komputer, 1(2), 56-65.

Wisnu Wirawan, P. (2011). Pengembangan Kemampuan E-Learning Berbasis Web ke dalam M Learning. Jurnal Masyarakat Informatika, 2(4). 